\title{
Equality as a Principle of the Networked World? An Exploratory Search for 'Cyber-Equality' in the Field of Internet Governance
}

\author{
Nula Frei* \\ Institute for European Law, University of Fribourg, Fribourg, Switzerland \\ nula.frei@unifr.ch
}

$\begin{array}{ll}\text { Abstract } & 627 \\ \text { Keywords } & 628 \\ \text { I. Introduction } & 628 \\ \text { II. The Principle of Equality and Its Foundations in International Law } & 631 \\ \text { III. Networked Inequality } & 635 \\ \text { IV. Tracking Down Equality in Internet Governance } & 638 \\ \text { 1. ICANN Bylaws } & 640 \\ \text { 2. WSIS Outcome Documents } & 643 \\ \text { 3. NETmundial } & 644 \\ \text { 4. EU Digital Services Act Proposal } & 647 \\ \text { 5. The State of Equality in Internet Governance: An Interim Conclusion } & 648\end{array}$

\begin{abstract}
Even though equality is a fundamental and transversal norm of international law, not much has been written about its role for cyberspace. The utopia of the 'inventors' of the internet was to create an open, transparent, and democratic space, and early proponents of cyberfeminism even believed that gender differences in general would disappear by improving technology. However, a look at the status quo suggests that cyberspace might currently be even farther away from an egalitarian ideal than the offline world. While openness, universality, and bottom-up procedures, inter alia, are widely accepted as foundational values of cyberspace and of internet governance, it seems that equality has not yet been discussed in depth, despite the apparent signs of what can be called 'cyber-inequality'. This article undertakes a first step in this direction. It critically examines cyber-equality, i. e., the status quo of equality in cyberspace, and analyses several key documents of internet
\end{abstract}

\footnotetext{
* The author would like to thank the anonymous reviewer as well as Dr Raffaela Kunz for helpful comments on the manuscript.
} 
governance from an equality perspective. This analysis allows for some preliminary conclusions, and to lay a foundation for future research, which will be outlined in the final section of this article. The article reveals that there is currently no consistent or comprehensive approach to addressing equality issues in internet governance and that much more research will be needed to better understand the topic and to embed equality considerations in internet governance.

\section{Keywords}

internet governance - equality - non-discrimination - technology

\section{Introduction}

Equality is a fundamental value and a basic principle of liberal democratic societies and is mirrored in several international treaties, customs, principles, and procedures. Deriving directly from the principle of human dignity, it forms a cornerstone of justice and fairness: Treating people differently because of personal, innate or immutable characteristics, such as their gender, ethnicity, class, religion, sexual orientation, would be unfair and a violation of the inherent human dignity of every human being. ${ }^{1}$

However, even though equality is of such fundamental value in the 'offline world', not much is known about its role for cyberspace. While the utopia of the 'inventors' of the Internet was to create an open, transparent, and democratic space, and theorists such as Donna Haraway believed that technology would help making our societies more egalitarian, ${ }^{2}$ a look at the status quo suggests that cyberspace might currently be even farther away from an egalitarian ideal than the offline world: As this contribution will show, not only is the technology needed for the running of Internet applications mostly designed by white, well-educated men, but also is access to Internet distributed unequally along lines of race, class, and gender. ${ }^{3}$ Moreover, once access is gained, the possibilities for enjoyment of the Internet are unequally dis-

1 Walter Kälin and Jörg Künzli, The Law of International Human Rights Protection (2nd edn, Oxford, New York: Oxford University Press 2019), 336; Charles Taylor and Amy Gutmann (eds), Multiculturalism and 'The Politics of Recognition' (Princeton: Princeton University Press 1992), $13 \mathrm{f}$.

2 Donna Haraway, 'A Manifesto for Cyborgs: Science, Technology, and Socialist Feminism in the 1980s', Socialist Review 80 (1985), 65-108.

3 See below, section III. 
tributed, with women, queer persons, persons of colour, or religious minorities being more often hindered from fully participating online by different forms of cyber violence and other acts with chilling effect on their enjoyment of this technology. Despite these apparent signs of what will hereinafter be called 'cyber-inequality', and despite the fact that cyberspace is not a valuefree space per se, ${ }^{4}$ equality in cyberspace has not yet been discussed in depth. Some soft-law documents of Internet governance do mention equality, but the academic discussion has so far only highlighted specific aspects of the problem, for example, participation of women in Internet governance, ${ }^{5}$ queer approaches to Internet governance, ${ }^{6}$ the digital divide, ${ }^{7}$ or online violence. ${ }^{8}$ While the academic discussion on Internet and Human Rights has advanced

4 For example, openness, universality, and bottom-up procedures, inter alia, are widely accepted as foundational values of cyberspace and of Internet governance, see Lawrence Lessig, 'Open Code and Open Societies: Values of Internet Governance', Chicago-Kent Law Review 74 (1999), 1405-1420; Hans Morten Haugen, 'The Crucial and Contested Global Public Good: Principles and Goals in Global Internet Governance', Internet Policy Review 9 (2020), 1-22.

5 Association for Progressive Communications (APC) and Humanist Institute for Development Cooperation (Hivos), Global Information Society Watch 2013: Women's Rights, Gender and ICTs (1st edn, Montevideo: APC/Hivos 2013); Heike Jensen, 'Whose Internet Is It Anyway? Shaping the Internet - Feminist Voices in Governance Decision Making' in: APC/ Hivos, Global Information Society Watch 2013: Women's Rights, Gender and ICTs, (1st edn, Montevideo: APC/Hivos 2013), 55-59; Judy Wajcman, Feminism Confronts Technology (Cambridge: Polity Press 1991).

6 Monika Zalnieriute, 'The Anatomy of Neoliberal Internet Governance. A Queer Critical Political Economy Perspective' in: Diane Otto (ed.), Queering International Law: Possibilities, Alliances, Complicities, Risks (New York: Routledge 2017), 53-73.

7 Jan A. G. M. van Dijck, 'A Theory of the Digital Divide' in: Massimo Ragnedda and Glenn W. Muschert (eds), The Digital Divide: The Internet and Social Inequality in International Perspective (London: Routledge 2013), 29-53; Jan A. G. M. van Dijk, 'Digital Divide Research, Achievements and Shortcomings', Poetics 34 (2006), 221-235; Paul DiMaggio, Eszter Hargittai, Coral Celeste and Steven Shafer, 'Digital Inequality: From Unequal Access to Differentiated Use' in: Kathryn Neckerman (ed.), Social Inequality (New York: Russell Sage Foundation 2004), 355-400; Eszter Hargittai and Yuli Patrick Hsieh, 'Digital Inequality' in: William H. Dutton (ed.), The Oxford Handbook of Internet Studies, Vol. 1 (Oxford: Oxford University Press 2013); Pippa Norris, Digital Divide: Civic Engagement, Information Poverty, and the Internet Worldwide (Cambridge: Cambridge University Press 2001); OECD, Bridging the Gender Digital Divide (2018); Bridgette Wessels, 'The Reproduction and Reconfiguration of Inequality: Differentiation and Class, Status and Power in the Dynamics of Digital Divides' in: Massimo Ragnedda and Glenn W. Muschert (eds), The Digital Divide: The Internet and Social Inequality in International Perspective (London: Routledge 2013), 17.

8 Kim Barker and Olga Jurasz, Online Misogyny as a Hate Crime: A Challenge for Legal Regulation? (London: Routledge 2019); Kim Barker and Olga Jurasz, 'Online Violence against Women as an Obstacle to Gender Equality: A Critical View from Europe', European Equality Law Review 1 (2020), 47-60; Maeve Duggan, Online Harassment 2017, 11 July 2017, <https:// www.pewresearch.org/>. 
considerably in the last years ${ }^{9}$ and it is widely accepted that International Human Rights Law also applies in cyberspace, ${ }^{10}$ the specific topic of equality and non-discrimination remains under-researched and under-theorised.

This article undertakes a first step in closing this research gap and aims to find out to what extent the principle of equality is already implicitly or explicitly addressed in the field of Internet governance. To this end, an exploratory content analysis of key documents of Internet governance, most of them soft law, will be conducted. This analysis will make it possible to draw initial conclusions about the role and place of equality in Internet governance and to identify existing gaps. While this study is only a first step with a limited selection of cases, and hence cannot answer all the questions that arise around equality in Internet governance, it will allow me to formulate a research agenda to advance the cause of anchoring equality in international Internet law. The article therefore proceeds as follows: It briefly describes the principle of equality in international law (II.) as well as the status quo of equality in cyberspace by identifying three dimensions of networked inequality (III.). It then analyses a selection of key documents of Internet governance from an equality perspective (IV.). This section undertakes a content analysis of those documents while paying particular attention to the three dimensions of networked inequality as described in section III. The goal of this section is to come to preliminary conclusions, and to lay a foundation for future research, which will then be outlined at the end of this contribution. The following documents will be examined: The bylaws of the Internet Corporation for Assigned Names and Numbers (ICANN) (IV. 1.), the outcome documents of the two World Summits on the Information Society (WSIS) (IV. 2.), the multistakeholder statement of the NETmundial conference (IV. 3,) and the Proposal for an European Union (EU) Digital

9 See, inter alia, Jonathan Andrew and Frédéric Bernard (eds), Human Rights Responsibilities in the Digital Age: States, Companies, and Individuals (London: Hart Publishing 2021); Molly K. Land and Jay D. Aronson (eds), New Technologies for Human Rights Law and Practice (Cambridge: Cambridge University Press 2018)>; Meryem Marzouki and Rikke Frank Joergensen, 'A Human Rights Assessment of the World Summit on the Information Society', Information Technologies and International Development 1 (2005), 86-88; Milton Mueller and Farzaneh Badiei, 'Requiem for a Dream: On Advancing Human Rights via Internet Architecture', Policy \& Internet 11 (2019), 61-83; Anne Peacock, Human Rights and the Digital Divide (London: Routledge 2019); Susan Perry and Claudia Roda, Human Rights and Digital Technology: Digital Tightrope (London: Palgrave Macmillan 2017); Ben Wagner, Matthias C. Kettemann and Kilian Vieth (eds), Research Handbook on Human Rights and Digital Technology: Global Politics, Law and International Relations (Cheltenham: Edward Elgar Publishing 2019); Monika Zalnieriute and Stefania Milan, 'Internet Architecture and Human Rights: Beyond the Human Rights Gap’, Policy \& Internet 11 (2019), 6-15.

10 ECtHR, Delfi AS v. Estonia, judgement of 16 June 2015, no. 64569/09; Beizaras and Levickas v. Lithuania, judgement of 14 January 2020, no. 41288/15. 
Services Act (IV. 4.). The actors examined are private regulators (ICANN), an intergovernmental forum (WSIS), an international bottom-up multistakeholder initiative (NETmundial), and a supranational organisation (European Union) and thus represent the variety of actors active in Internet governance. This part will reveal that there is currently no consistent or comprehensive approach to addressing equality issues in Internet governance and that more research will be needed to better understand the topic and to embed equality considerations in Internet governance. By way of a conclusion, the chapter draws a research agenda that should inspire and help guide future enquiries (V.).

\section{The Principle of Equality and Its Foundations in International Law}

The principle of equality speaks to our intuitive understanding of fairness and justice: Treating likes unlike or treating unlikes alike is perceived as unjust or unfair. ${ }^{11}$ Equality has a centuries-old intellectual tradition. ${ }^{12}$ The classical principle of equality goes back to Aristotle: ${ }^{13}$ that what is equal should be treated equally and what is unequal should be treated unequally. In the Enlightenment, the idea of equality achieved a renaissance in the struggle against feudal social relations and was seen as an important foundation of the modern social order as well as of democracy. Equality is also an important element of liberal state theories. ${ }^{14}$ In this understanding, equal treatment is not only a fundamental right, but also a basic principle of every democratic constitutional state, which must treat all of its citizens equally.

However, equality in and of itself is an 'empty idea'. ${ }^{15}$ What equality means exactly, who is to be treated equally with whom, and which situations,

11 Kristin Henrard, 'Equality of Individuals' in: Rüdiger Wolfrum (ed.), MPEPIL (online edn. Oxford: Oxford University Press 2008); John McMillan and Jeanne Snelling, 'Equality: Old Debates, New Technologies' in: Roger Brownsword, Eloise Scotford and Karen Yeung (eds), The Oxford Handbook of the Law and Regulation of Technology 1 (2017), 73.

12 Jarlath Clifford, 'Equality' in: Dinah Shelton (ed.), The Oxford Handbook of International Human Rights Law (2013), 422.

13 Aristotle, Nicomachean Ethics (Cambridge: Cambridge University Press 2000), Book V3, paras 1131a-b.

14 Daniel Moeckli, 'Equality and Non-Discrimination' in: Daniel Moeckli, Sangeeta Shah and Sandesh Sivakumaran (eds), International Human Rights Law (2nd edn, Oxford: Oxford University Press 2018), 148.

15 Peter Westen, 'The Empty Idea of Equality', Harv. L. Rev. 95 (1982), 537-596; Kent Greenawalt, 'How Empty Is the Idea of Equality?', Colum. L. Rev. 83 (1983), 1167-1185; Moeckli (n. 14), 149. 
circumstances, characteristics are considered equal or comparable, does not result from the philosophical foundations of equality itself, but awaits to be filled with normative content. ${ }^{16}$ This, in turn, is a political question that often depends on the prevailing views of a time. Aristotle, for example, could still assume the equality of only the male active citizens of Athens. The Enlightenment thinker John Locke also primarily had male equality in mind, ${ }^{17}$ which per se excluded all women as well as the unfree (slaves) from the claim to equality. ${ }^{18}$ Today, equality on the basis of immutable characteristics such as gender, race, and ethnic origin, as well as religion and other characteristics, is undisputed in international law. ${ }^{19}$

While equality as the ultimate social ideal is widely accepted, the way of achieving equality is not determined by the mere ideal of equality itself. Essentially, two different types of equality can be distinguished, namely formal and substantive equality. ${ }^{20}$ The concept of formal equality requires equal treatment. This is, to a certain extent, the most intuitive concept of equality. ${ }^{21}$ Formal equality is based on a procedural understanding of equality: in a concrete case of application, comparable situations must not be treated unequally. ${ }^{22}$ Within the concept of formal equality, a distinction is made between direct and indirect unequal treatment: While direct unequal treatment is linked to a protected characteristic and thus creates a clearly recognisable inequality, indirect unequal treatment happens when a seemingly neutral criterion, rule, or practice has considerably more negative consequences on certain protected groups than on others. ${ }^{23}$ Formal equality obliges the state, legally speaking, to an abstention: it must refrain from any unequal treatment, whether direct or indirect.

The second concept of equality is the so-called substantive equality. This concept looks not at the process, but at the result. Only when a state of substantive equality (for example, equal number of female and male representatives, equal income for work of equal value, etc.) has been reached, is

16 Clifford (n. 12), 424.

17 John Locke, Two Treatises of Government (2nd ed., 2003), second treatise, para. 2.

18 Sandra Fredman, Discrimination Law (2nd edn, Oxford: Oxford University Press 2011), 4.

19 Moeckli (n. 14), 154.

20 See, for example, Fredman (n. 18), 4; Henrard (n. 11); Moeckli (n. 14), 149; Judith Squires, 'Equality and Difference' in: John S. Dryzek, Bonnie Honig and Anne Phillips (eds), The Oxford Handbook of Political Theory (Oxford: Oxford University Press 2009), 471.

21 Fredman (n. 18), 8; Moeckli (n. 14), 157.

22 Fredman (n. 18), 8 ('Treating likes alike'); Henrard (n. 11), 601; Moeckli (n. 14), 149.

23 Moeckli (n. 14), 156; See also the legal definition of indirect discrimination in the EU equality directives: Art. 2(2) Directive 2000/43/EC; Art. 2(2) Directive 2000/78/EC; Art. 2(1) Directive 2006/54/EC. 
the ideal of equality achieved. ${ }^{24}$ Substantive equality deviates from the procedural understanding of equality in the sense of equal treatment in that it allows, for example, for preferential treatment of members of certain groups in order to compensate for the effects of past unequal treatment and to achieve substantive equality. Substantive equality requires the State not only to abstain, as in the case of formal equality, but under certain circumstances also to take action, and therefore constitutes a positive obligation to take measures.

Unequal treatment that is linked to a characteristic protected under $\mathrm{Hu}-$ man Rights Law, namely gender, race or ethnicity, disability, religion, and, at least in the European context, age, and sexual orientation, is particularly reprehensible and can only be justified legally if certain specific conditions are met. As a rule, unequal treatment based on one of these characteristics can only be justified if it pursues a particularly important, legitimate aim and if the measure is proportionate. ${ }^{25}$

In international law, equality is enshrined in all universal Human Rights treaties and can be considered a structural principle of International Human Rights Law. ${ }^{26}$ The Universal Declaration of Human Rights ${ }^{27}$ (Articles 1 and 2), the International Covenants on Civil and Political Rights ${ }^{28}$ (Articles 2(1), 3 and 26) and on Economic, Social and Cultural Rights ${ }^{29}$ (Articles 2(2) and 3), as

24 Catherine Barnard and Bob Hepple, 'Substantive Equality', CLJ 59 (2000), 562-585; Sandra Fredman, 'Changing the Norm: Positive Duties in Equal Treatment Legislation', Maastricht J. Eur. \& Comp. L. 12 (2005), 369-397; Sandra Fredman (n. 18), 14; Sandra Fredman, 'Emerging from the Shadows: Substantive Equality and Article 14 of the European Convention on Human Rights', HRLR 16 (2016), 273-301; Sandra Fredman, 'Substantive Equality Revisited', I CON 14 (2016), 712-738; Catharine A. MacKinnon, 'Substantive Equality Revisited: A Reply to Sandra Fredman', 14 I CON 14 (2016), 739-746; Moeckli (n. 14), 150.

25 See generally, Human Rights Committee, General Comment No. 18 (1989), para. 13; Human Rights Committee, Gillot v. France, A/57/40 (15 July 2002), para. 13.2; ECtHR, Case Relating to Certain Aspects of the Laws on the Use of Languages in Education in Belgium (Belgian Linguistics Case) (No 2), judgement of 23 July 1968, 1 EHRR 252, para. 10; CERD, UN Committee on the Elimination of Racial Discrimination: Concluding Observations, Australia, CERD/C/AUS/CO/14 (14 April 2005), para. 24; CESCR, General Comment No. 20: Non-Discrimination in Economic, Social and Cultural Rights (Art. 2, para. 2, of the International Covenant on Economic, Social and Cultural Rights), E/C.12/GC/20, para. 13; Moeckli (n. 14), 158.

26 Clifford (n. 12), 430.

27 UN General Assembly, Universal Declaration of Human Rights, 10 December 1948, 217 A (III).

28 UN General Assembly, International Covenant on Civil and Political Rights, 16 December 1966, 999 UNTS 171 (ICCPR); see Human Rights Committee, General Comment No. 18 (1989).

29 UN General Assembly, International Covenant on Economic, Social and Cultural Rights, 16 December 1966, 993 UNTS 3 (ICESCR), see UN CESCR General Comment No. 20 (n. 25). 
well as all regional Human Rights treaties, ${ }^{30}$ acknowledge the principle of equality and the prohibition of discrimination that flows from this principle. On a global level, the Convention against Racial Discrimination, ${ }^{31}$ the Convention on the Abolition of all Forms of Discrimination against Women, ${ }^{32}$ the Convention on the Rights of the Child, ${ }^{33}$ and the Convention on the Rights of Persons with Disabilities ${ }^{34}$ contain group-specific provisions that aim to achieve equality.

While the principle of equality and its corresponding prohibition of discrimination under international law are primarily directed at the State in the form of a negative obligation, is not limited to this. Rather, the prohibition of discrimination and the principle of equality contain both an obligation to protect as well as an obligation to take measures to implement the principle of equality in the private sphere as well, and thus to strive for substantive equality. While there is no obligation under International Human Rights Law for private individuals (e. g. businesses or self-regulating actors) to treat others equally or to strive for substantive equality, there is an obligation on States to seek the realisation of this principle by regulating areas that are susceptible to inequality without State intervention. ${ }^{35}$ It is generally accepted under Human Rights Law that States must, under their obligation to protect, intervene and impose requirements for compliance with this principle if it is determined that self-regulation is not sufficient to prevent breaches of International Human Rights Standards. ${ }^{36}$ Since Internet governance is to a large extent dominated and regulated by private actors, this obligation to protect becomes particularly relevant. So far, however, there is only very limited

30 Such as the European Convention on Human Rights of 4 November 1950, 213 UNTS 221, ETs No. 5 in its Articles 14 ECHR and 1 of Additional Protocol No. 12, and the InterAmerican Convention on Human Rights of 22 November 1969, 1144 UNTS 123, OAS TS No. 36 in its Articles 1(1) and 24. See Caballero Ochoa and Aguilar Contreras, 'New Trends on the Right to Non-Discrimination in the Inter-American System of Human Rights', Inter-American \& European Human Rights Journal 8 (2016), 80-94; Oddný Mjöll Arnardóttir, Equality and Non-Discrimination under the European Convention on Human Rights (The Hague: Martinus Nijhoff 2003).

31 International Convention on the Elimination of All Forms of Racial Discrimination of 7 March 1965, 660 UNTS 13 (CERD).

32 Convention on the Elimination of All Forms of Discrimination against Women of 18 December 1979, 1249 UNTS 13 (CEDAW).

33 Convention on the Rights of the Child of 20 November 1989, 1577 UNTS 3 (CRC).

34 Convention on the Rights of Persons with Disabilities of 13 December 2006, 2515 UNTS 3.

35 Kälin and Künzli (n. 1), 343. See CESCR, General Comments Nos 16 of 11 August 2005, para. 18, and 20 of 2 July 2009, para. 39, as well as HRC, General Comments Nos 28 of 29 March 2000, paras $3 \mathrm{ff}$, and 18 of 10 November 1989, para. 5.

36 HRC, General Comment No. 31 of 26 May 2004, para. 8. 
practice by the international monitoring mechanisms on questions of equality in cyberspace. ${ }^{37}$

\section{Networked Inequality}

In the following paragraphs, I will take a closer look at the status of equality in cyberspace and in Internet governance in particular. Like technology in general, the Internet is often seen as 'neutral' and machines, programs, and code are often perceived to be free from human feelings and distortions. When looking at cyberspace through an equality lens however, one rapidly comes to the conclusion that cyberspace is not as 'objective' and 'neutral' as it is often perceived. For the sake of analysis, I will look at three ${ }^{38}$ dimensions of inequality in cyberspace, namely design of, access to, and enjoyment of the Internet. These three dimensions do not exist in isolation from each other. They are interlinked, mutually reinforcing,and influencing each other.

Firstly, the design and administration of the technologies necessary to keep the Internet operational is characterised by a significant underrepresentation of women and minorities amongst developers, ${ }^{39}$ which ultimately leads to an 'inherent masculinity'40 of the Internet infrastructure. It is no secret that the

37 The only judgement so far known is of the European Court of Human Rights, ECtHR, Buturugă v. Romania, judgement of 10 February 2020, no. 56867/15, where the Court pointed out that cyberbullying was currently recognised as an aspect of violence against women and girls, and that it could take on a variety of forms, including cyberbreaches of privacy, intrusion into the victim's computer and the capture, sharing and manipulation of data and images, including private data. The Court recognised a violation of Art. 3 i.c. w. Art. 14 ECHR.

38 DiMaggio, Hargittai, Celeste and Shafer (n. 7), distinguish between five aspects of inequality related to information and communcation technologies: (1) the quality of hardware, software, and network connection; (2) autonomy of use; (3) skill; (4) availability of social support; and (5) extent and quality of use. Hargittai and Hsieh (n. 7), differentiate between (1) access and (2) skills and uses.

39 See, for example, already the 'Pioneers Gallery' of the World Wide Web, available at $<$ http://www.wiwiw.org/>. Ironically, it was a woman who invented the first programming language (Ada Lovelace), and the first 'computers' were mainly women. In fact, in the $1940 \mathrm{~s}$ to the $1960 \mathrm{~s}$, programming was seen as a typical women's job: Programming was seen as similar to following a recipe or putting together a menu. In addition, programming did not require much physical strength, which was also seen as a clear advantage for women. Only in the $1970 \mathrm{~s}$ did programming become a typically male profession, which went hand in hand with an increased reputation and higher salaries. See Isabelle Collet, L'informatique a-t-Elle Un Sexe? Hackers, Mythes et Réalités (Paris: Editions L'Harmatan 2006); Isabelle Collet, 'Effet de genre: le paradoxe des études d'informatique', Tic E Société 5 (2011), 12-34.

40 Some theorists argue that male values have been institutionalised in the technology through its creators, embedding a cultural association with masculine identity in the technology itself: Cheris Kramarae (ed.), Technology and Women's Voices: Keeping in Touch (London: Routledge 1988); Wajcman (n. 5). In the terminology of Green, Owen, and Pain (1993), the technology may be 'gendered by design', see Eileen Green, Jenny Owen and Den Pain (eds), Gendered by Design? Information Technology and Office Systems (London: Taylor \& Francis Ltd. 1993). 
profession of computer science, computer engineers, programming, is to a large extent a 'male profession', despite ongoing efforts by governments and companies, for example, to inspire and promote women for these professions. ${ }^{41}$ Also, women are less represented in decision-making processes on Internet governance. ${ }^{42}$ This might cause worries from an equality perspective, since code itself can be seen as a form of law, ${ }^{43}$ leading to potentially discriminatory outcomes such as search engines reinforcing racism. ${ }^{44}$ Choices made about technologies of Internet governance do not merely depend upon technical questions, but on balancing the interests and values of the social groups involved in these choices. ${ }^{45}$ This underrepresentation of certain groups and overrepresentation of others might also have implications for the governance of the Internet. The multistakeholder approach, ${ }^{46}$ as well as the bottom-up approach, which are supposed to stand for greater inclusion of all those affected by Internet regulation, come to a limit if those working in this area all belong to the same group.

Secondly, access to Internet is distributed unequally along lines of race, class, age, and gender. Not only does access to Internet and information depend on (Internet) literacy, but also on the place of residence (including country of residence) and on economic resources, which are themselves distributed unequally amongst the abovementioned lines. Essentially, the 'digital divide' mirrors existing power structures and lines of inequality in the offline world. ${ }^{47}$ This 'digital divide', and in particular the 'digital gender divide', has been known for many decades now. However, it has been mostly the subject of sociological inquiry. ${ }^{48}$ Legal analyses of this phenomenon are largely lacking. ${ }^{49}$

41 See, for example, Barker and Jurasz, Online Violence (n. 8), 55. To the evolution from a female to a male profession see Collet (n. 39).

42 Association for Progressive Communications, Critically Absent: Women's Rights in Internet Governance (2012), available at <https://internetdemocracy.in/>; Jensen (n. 5).

43 Lawrence Lessig, Code and Other Laws of Cyberspace (New York: Basic Books 1999).

44 Safiya Umoja Noble, Algorithms of Oppression: How Search Engines Reinforce Racism (New York: NYU Press 2018).

45 Laura DeNardis, 'Hidden Levers of Internet Control: An Infrastructure-Based Theory of Internet Governance', Information, Communication E Society 15 (2012), 720-738 (722); Andrew Feenberg, Questioning Technology (London: Routledge 1999); Helen Nissenbaum, 'How Computer Systems Embody Values', Computer 34 (2001), 118-120.

46 Christine Kaufmann, 'Multistakeholder Participation in Cyberspace', SRIEL 26 (2016), 217-234.

47 Wessels (n. 7).

48 See, for example, Norris (n. 7); van Dijk (n. 7); Jan A. G. M. van Dijck, 'A Theory of the Digital Divide' in: Massimo Ragnedda and Glenn W. Muschert (eds), The Digital Divide: The Internet and Social Inequality in International Perspective (London: Routledge 2013), 29-51; OECD (n.7); Wessels (n. 7).

49 One notable exception is: Peacock (n. 9). 
Finally, also the possibilities for enjoyment of the Internet are unequally distributed. Women, queer persons, Persons of Colour $(\mathrm{PoC})$, or religious minorities are more often subject to forms of cyber violence such as cyberharassment or cyberstalking, image-based sexual abuse (also referred to as 'revenge pornography') and other forms of technology-mediated harm. ${ }^{50}$ Studies show that the majority of those particularly affected by digital violence are of female self-assignment. ${ }^{51}$ Online violence, on one hand, negatively affects the enjoyment of other rights of the victims. ${ }^{52}$ For example, hate speech or threats have a chilling effect on the exercise of the right to freedom of expression or participation in democratic discourse (e.g. in social media). Online stalking affects the victims' right to privacy. On the other hand, since those crimes happen more often to certain groups, they also amount to discriminatory violation of other rights, such as the right to privacy and the right to freedom of expression. While those acts are typically committed by private actors and therefore do not constitute direct violations of Human Rights guarantees, a State is certainly in violation of his obligation to protect if no preventive and/or repressive measures are taken against those acts.

These dimensions of inequality influence each other. For example, a causal relationship is discernible between the underrepresentation of women and Persons of Color in the process of designing Internet technology and those groups' difficulties in the enjoyment of cyberspace, due to, for example, a lack of technological remedies to discriminatory online harm.

In sum, we can observe that the picture about the Internet's role for equality seems to be more complicated than was imagined by the 'inventors' of the Internet, who heralded it as the great potential equalizer ${ }^{53}$ and aspired to create an open, transparent, and democratic space. While early proponents of cyberfeminism such as Donna Haraway believed that society would become more equal by improving technology, ${ }^{54}$ a look at the status quo is rather disenchanting and leads the observer to feel that cyberspace might be even less egalitarian than the offline world.

50 Barker and Jurasz, Online Violence (n. 8).

51 Maeve Duggan, Online Harassment 2017 (Washington D. C.: Pew Research Center, July 2017). An EU-wide study came to similar conclusions, see Amnesty International, Amnesty Reveals Alarming Impact of Online Abuse against Women, 20. November 2017, <https:// www.amnesty.org/>.

52 Barker and Jurasz, Online Violence (n. 8), 55. The European Commission has recently acknowledged that online violence against women acts as a barrier to women's participation in public life, see European Commission, 'A Union of Equality: Gender Equality Strategy 2020 2025’, $\operatorname{COM}(2020) 152$ final, 5 March 2020, 5.

53 Hargittai and Hsieh (n. 7).

54 Haraway (n. 2). 


\section{Tracking Down Equality in Internet Governance}

Having established the fundamental nature of equality in the 'offline world' and in international law entails (section II.) as well as the existing inequalities in cyberspace (section III.), the coming section will analyse whether this situation is remedied in existing documents of Internet Governance. It therefore undertakes a content analysis of key documents of Internet governance from a variety of actors. The analysis pays particular attention to the three dimensions of networked inequality as described in section III. The goal of this section is explanatory: It will allow for an overview as well as preliminary conclusions, and thereby laying the foundations for future research. The following documents will be examined: The bylaws of the Internet Corporation for Assigned Names and Numbers ICANN (IV. 1.), the outcome documents of the two World Summits on the Information Society WSIS (IV. 2.), the multistakeholder statement of the NETmundial conference (IV. 3.), and the Proposal for an EU Digital Services Act (IV. 4.). While there are many more soft law ${ }^{55}$ and hard law ${ }^{56}$ documents that await to be analysed from an equality perspective, the documents examined here have been chosen for analysis because they represent regulations from a variety of actors (a private regulator, an intergovernmental forum, an international bottom-up multistakeholder initiative, and a supranational organisation) and therefore also exemplify the fragmented and multipolar landscape of Internet governance.

\section{ICANN Bylaws}

ICANN, the Internet Corporation for Assigned Names and Numbers, is a private non-profit organisation under Californian law and coordinates the allocation of unique names and addresses on the Internet (namely the coordination of the Domain Name System and the allocation of IP addresses). This makes ICANN one of the most important players when it comes to regulating the infrastructure of the Internet. The role of Internet infrastructure for

55 This includes the various outcome documents of the annual Internet Governance Fora, further Internet-related regulations and directives of the European Union, recommendations and statements of the Council of Europe and the OECD, laws at the national level, basic documents of bottom-up initiatives such as the Internet Society and the Internet Engineering Task Force, statements and reports of the various organs and rapporteurs of the United Nations, and many more.

56 Especially the Council of Europe Convention on Cybercrime of 23 November 2001, CETS No. 185. 
fundamental rights is increasingly appreciated, recognising that arrangements of technical architecture are inherently arrangements of power. ${ }^{57}$ The ICANN Bylaws, which could be described as the ICANN's 'constitution', have been revised and replaced several dozens of times. ${ }^{58}$ The current version dates from November 2019.59

Right at the very beginning of the Bylaws, ICANN commits to its 'Core Values', which include that ICANN carries out its activities 'in conformity with relevant principles of international law and international conventions and applicable local law [...]'.60 Even though the Bylaws do not specify the 'relevant principles' that should be observed, it can be assumed that the principle of equality, due to its structural nature, ${ }^{61}$ would also form part of this list. The relevant principles of international law and conventions should also include the principle of equality and non-discrimination under international law. The non-discriminatory application of ICANN's policies is also mentioned as a special obligation under this Bylaw: 'Make decisions by applying documented policies consistently, neutrally, objectively, and fairly, without singling out any particular party for discriminatory treatment (i.e. making an unjustified prejudicial distinction between or among different parties).' ${ }^{\prime}$ ICANN thus commits itself to a non-discriminatory application of its policies in practice. However, this Bylaw is formulated in a very general and imprecise manner; one does not know, for example, which types of distinctions are inadmissible and which ones might be required to avoid indirect discrimination.

When it comes to the composition of its Board of Directors, the Bylaws place great emphasis on diversity. According to Bylaw 7.2 (b), 'the Nominating Committee shall ensure that the Board is composed of Directors who, in the aggregate, display diversity in geography, culture, skills, experience, and perspective'. As discussed above in section III., one of the causes and also one of the dimensions of inequality in cyberspace is that Internet policy makers are often male and white. Bylaw 7.2 (b) attempts to address this through an explicit commitment to diversity in the composition of the Board of Directors. However, 'classic' discrimination categories recognised under International Human Rights Law such as gender, race, religion, age, or sexual orientation are not included, and instead emphasis is placed on geographic

57 DeNardis (n. 45), 721; Zalnieriute and Milan (n. 9), 6; for a more critical account on the linking of human rights and internet architecture see Mueller and Badiei (n. 9), 61.

58 See the ICANN Bylaws archive: <https://www.icann.org/>.

59 Available at $<$ https://www.icann.org/>.

60 ICANN Bylaw 1.2 (a).

61 See above, section II.

62 ICANN Bylaw $1.2(\mathrm{a})(\mathrm{v})$. 
and cultural diversity as well as skills, experience and perspectives. Of course, persons with different gender, religion, race, age, or sexual orientation also have different 'experiences' or 'perspectives', but this interpretation of the Bylaw is not the only one possible. 'Experience and perspective' can also simply be interpreted as covering different professional backgrounds, which could still lead to a homogenous composition of the Board, since, as has been explained in section III. above, white men are overrepresented in most fields of tech and Internet governance.

Finally, the topic of Human Rights (and thus, implicitly, also equality) is mirrored in the recently added 'Human Rights Bylaw' of 2019. According to this provision, one of ICANN's Core Values is the 'respecting [of] internationally recognised human rights as required by applicable law' ${ }^{63}$ However, the Bylaws directly limit this commitment by specifying that 'This Core Value does not create, and shall not be interpreted to create, any obligation on ICANN outside its Mission, or beyond obligations found in applicable law. This Core Value does not obligate ICANN to enforce its Human Rights obligations, or the Human Rights obligations of other parties, against other parties.' Furthermore, Bylaw 27.2 (b) states that the Human Rights Bylaw cannot be invoked in the reconsideration process (Section IV. 2.), or in the independent review process (Section IV. 3.) and is therefore not an enforceable obligation in internal complaints procedures, which somehow contradicts ICANN's above-mentioned commitment to non-discriminatory application of its policies. The idea that ICANN would commit itself to strong Human Rights obligations, particularly in the field of equality, is thus very quickly dashed here. ${ }^{64}$ Rather, equality seems to be conceptualised as a value without further operationalisation for daily practice.

\section{WSIS Outcome Documents}

The World Summit on the Information Society (WSIS) was a United Nations-sponsored world summit on information and communications that was organised by the International Telecommunication Union (ITU) and consisted of two parts. The first part took place in Geneva (Switzerland) from 10 to 12 December 2003 and had about 12,000 participants. The second part,

63 ICANN Bylaw 1.2 (b)(viii).

64 See also the criticism of the 'Human Rights Bylaw' by Monika Zalnieriute, 'From Human Rights Aspirations to Enforceable Obligations by Non-State Actors in the Digital Age: The Example of Internet Governance and ICANN', Yale Journal of Law E Technology 21 (2019), 278-336 and Monika Zalnieriute, 'Human Rights Rhetoric in Global Internet Governance: New ICANN Bylaw on Human Rights', Harvard Business Law Review 10 (2020), 1-40. 
held in Tunis (Tunisia) from 16 to 18 November 2005, was attended by about 17,000 delegates from 175 countries. ${ }^{65}$

The Outcome Documents of these two summits have no legally binding force, but they express the common views of the participants to the Summits and can therefore be seen as international soft law and provide insights into the role of equality in Internet governance. They consist of the Geneva Declaration of Principles, the Geneva Plan of Action, the Tunis Commitment and the Tunis Agenda for the Information Society. ${ }^{66}$

The first principle of the Geneva Declaration is called 'Our Common Vision of the Information Society'. There, the representatives express their 'common desire and commitment to build a people-centred, inclusive, and development-oriented Information Society, where everyone can create, access, utilise, and share information and knowledge, enabling individuals, communities, and peoples to achieve their full potential in promoting their sustainable development and improving their quality of life, premised on the purposes and principles of the Charter of the United Nations and respecting fully and upholding the Universal Declaration of Human Rights.' One of the key principles of this 'Information Society for All' is 'Access to information and Knowledge', which also includes universal access to the Internet, ${ }^{67}$ and therefore one of the above-mentioned dimensions of inequality in cyberspace. However, the Geneva Declaration only refers to universal access in relation to geographical location, so that no region or country of the world should be cut off from access to the Internet, while the 'digital gender divide' is not addressed. Principle 8 calls for 'cultural diversity and identity, linguistic diversity and local content'. ${ }^{68}$ Here, too, it is not a diversity of identities that is meant, but rather geographical, cultural, and linguistic diversity.

Principle 6 calls for an 'Enabling Environment' and states that ' $[t]$ he rule of law [...] is essential for building a people-centred Information Society. Governments should intervene, as appropriate, to correct market failures, to maintain fair competition, to attract investment, to enhance the development of the ICT [Information and Communication Technology] infrastructure and applications, to maximise economic and social benefits, and to serve national priorities. ${ }^{69}$ From an equality point of view (and a Human Rights perspective in general) it seems striking that no intervention by governments is foreseen regarding the compliance with Human Rights, especially the realisation of the principle of equality.

\footnotetext{
65 See $<$ https://www.itu.int/>.

66 The WSIS Outcome Documents are available at $<$ https://www.itu.int/>.

67 Geneva Declaration of Principles (n. 66), No. 28.

68 Geneva Declaration of Principles (n. 66), Nos 52-54.

69 Geneva Declaration of Principles (n. 66), No. 39.
} 
Human Rights are only mentioned under the title 'Ethical dimensions of the Information Society' (principle 10). ${ }^{70}$ According to this principle, the Information Society should 'respect peace and uphold the fundamental values of freedom, equality, solidarity, tolerance, shared responsibility, and respect for nature. ${ }^{71}$ Equality is thus conceptualised not as a right but as a value, in a line with other rather open concepts such as solidarity, tolerance, responsibility and the respect for nature. If one continues reading, one also sees that only personal privacy, and the right to freedom of thought, conscience, and religion are mentioned as Human Rights to be protected: 'The use of ICTs and content creation should respect Human Rights and fundamental freedoms of others, including personal privacy, and the right to freedom of thought, conscience, and religion in conformity with relevant international instruments. ${ }^{72}$ Equality is not mentioned as a Human Right worth protecting in cyberspace.

At least, principle 10 addresses the need to combat discriminatory content online: 'All actors in the Information Society should take appropriate actions and preventive measures, as determined by law, against abusive uses of ICTs, such as illegal and other acts motivated by racism, racial discrimination, xenophobia, and related intolerance, hatred, violence, all forms of child abuse, including paedophilia and child pornography, and trafficking in, and exploitation of, human beings. ${ }^{73}$ However, important forms of discriminatory online harm are not mentioned, especially transphobia, religious intolerance, and online violence against women, which can lead to the creation of a 'hierarchy of harms'. ${ }^{74}$

A few additional issues were raised in the Tunis Commitment, which, for example, explicitly recognises the existence of a digital gender divide: ${ }^{75}$ 'We reaffirm our commitment to women's empowerment and to a gender equality perspective, so that we can overcome this divide. We further acknowledge that the full participation of women in the Information Society is necessary to ensure the inclusiveness and respect for Human Rights within the Information Society. We encourage all stakeholders to support women's participation in decision-making processes and to contribute to shaping all spheres of the Information Society at international, regional and national levels. ${ }^{36}$ The

70 See, more generally, Marzouki and Joergensen (n. 9).

71 Geneva Declaration of Principles (n. 66), No. 56.

72 Geneva Declaration of Principles (n. 66), No. 58.

73 Geneva Declaration of Principles (n. 66), No. 59.

74 This term was coined, with reference to European (non-)regulation of online harm, by

Barker and Jurasz, Online Violence (n. 8), 57.

75 Tunis Commitment (n. 66), No. 23.

76 Tunis Commitment (n. 66), No. 23. 
equality dimensions of design and of access to Internet are thus implicitly addressed in the Tunis Commitment.

To conclude, while some sensitivity to equality online can be identified in the WSIS outcome documents, it can be observed that the full dimension of inequality in cyberspace was not addressed by the drafters of those documents. Equality seems to be understood as a value rather than an enforceable Human Right.

\section{NETmundial}

The NETmundial initiative was a transnational platform that followed the multistakeholder approach and aimed to provide a forum for discussion on Internet regulation. ${ }^{77}$ The first and, so far only meeting took place in São Paulo in April 2014 and gathered a total of 1,480 stakeholders from 97 countries, representing governments, business, and civil society. The key outcome was the non-binding Multistakeholder Statement, which sets out a series of principles for Internet governance and outlines a roadmap for the future of Internet regulation. The NETmundial initiative was not without controversy and, due to different factors, collapsed not long after its taking place. Nevertheless, and despite its legally non-binding nature, the Multistakeholder Statement remains an important document for Internet governance and for analysing the place of equality in it.

The Multistakeholder Statement lists 'Human Rights and Shared Values' as the first in a series of Internet Governance Principles. In remarkable contrast to the other documents examined so far, the statement formulates that ' $r$ ] ights that people have offline must also be protected online, in accordance with international Human Rights legal obligations, including the International Covenants on Civil and Political Rights and Economic, Social and Cultural Rights, and the Convention on the Rights of Persons with Disabilities'. This corresponds to the principle of 'what applies offline, also applies online' developed by the United Nations Human Rights Council. ${ }^{78}$ However, as promising as the NETmundial Multistakeholder Statement starts, as disappointing it continues. Reading on, the Statement only mentions the 'traditional' rights that are usually invoked when talking about matters online: Freedom of expression, freedom of association, privacy, freedom of information, as well as accessibility (for persons with disabilities), and a right to development, but it does not mention equality. ${ }^{79}$

$77<$ https://netmundial.br/>.

78 UNHRC Res 20/8 of 5 July 2012.

79 NETmundial Multistakeholder Statement available at $<$ https://netmundial.br/>, 4. 
The Multistakeholder Statement goes on to enumerate the so-called 'Internet Governance Process Principles'. The process of Internet governance shall be 'inclusive and equitable', among other characteristics such as multistakeholder, open, participative, consensus driven, transparent, accountable, distributed, collaborative, and enabling meaningful participation. This could be understood as addressing the problem of under-representation of certain groups (see above, section III.) in the design of Internet governance. However, this principle is formulated so vaguely that such a conclusion is not necessarily compelling and is probably more wishful thinking by the author. In any case it could also be interpreted differently, since it is only mentioned that 'Internet governance institutions and processes should be inclusive and open to all interested stakeholders. Processes, including decision making, should be bottom-up, enabling the full involvement of all stakeholders, in a way that does not disadvantage any category of stakeholder.' ${ }^{80}$

Equality is also mentioned in the 'Roadmap for the future evolution of the Internet Governance'. As one of the 'Issues that deserve attention of all stakeholders in the future evolution of Internet governance', the statement also mentions that ' $[t]$ here should be meaningful participation by all interested parties in Internet governance discussions and decision-making, with attention to geographic, stakeholder and gender balance in order to avoid asymmetries'.

Apart from this, however, equality is not present in the NETmundial Multistakeholder Statement, and the question of cyberviolence, for example, is not addressed at all. We can conclude that, although the Multistakeholder Statement appears advanced compared to the other documents analysed so far in terms of mentioning Human Rights and equality or non-discrimination, the overall result is rather dire as well.

\section{EU Digital Services Act Proposal}

The European Union is increasingly becoming an important player when it comes to regulating the Internet. Of all the actors analysed here, it is the only one that has a state-like character and can issue legally binding and enforceable regulations. I will analyse here the proposal for a 'Digital Services Act', ${ }^{81}$ which was presented by the European Commission in December 2020

80 NETmundial Multistakeholder Statement (n. 79), 6.

81 European Commission, Proposal for a Regulation of the European Parliament and of the Council on a Single Market For Digital Services (Digital Services Act) and amending Directive 2000/31/EC, 15 December 2020, COM (2020) 825 final. 
after a long period of drafting and consultations. At the time of writing, the package has not yet been discussed and adopted by Parliament and Council and it can be expected that the proposal will still undergo considerable amendments. Nevertheless, it is not too early to examine the proposal from an equality perspective.

Already in its Explanatory Memorandum, the proposal promises to be 'fully consistent [with] and further supports equality strategies adopted by the Commission in the context of the Union of Equality'. ${ }^{82}$ However, the Explanatory Memorandum does not enter into more detail, so that this sentence sounds more like an empty phrase that needed to be included for formal reasons in order to show that the proposal is in line with 'other Union policies'. At least, the Explanatory Memorandum accepts that 'specific groups or persons may be vulnerable or disadvantaged in their use of online services because of their gender, race or ethnic origin, religion or belief, disability, age, or sexual orientation. They can be disproportionately affected by restrictions and removal measures following from (unconscious or conscious) biases potentially embedded in the notification systems by users and third parties, as well as replicated in automated content moderation tools used by platforms.' ${ }^{33}$ The Memorandum then promises that 'The proposal will mitigate discriminatory risks, particularly for those groups or persons and will contribute to the protection of the rights of the child and the right to human dignity online. ${ }^{84}$ The proposal thus takes account of the 'enjoyment' dimension of networked inequality explained in section III.

The recitals of the proposed regulation on a Digital Services Act contain equality considerations in several instances: Recital 3 combines the duty of responsible and diligent behaviour by providers of intermediary services with the right of Union citizens and other persons to exercise their fundamental rights guaranteed in the Charter of Fundamental Rights of the European Union, in particular the freedom of expression and information and the freedom to conduct a business, and the right to non-discrimination. ${ }^{85}$ Recital 12 clarifies that the concept of 'illegal content' should be defined broadly and should also cover content such as illegal hate speech or terrorist content and unlawful discriminatory content, unlawful non-consensual sharing of private images or online stalking. This partly addresses the critique of a 'hierarchy of harms' mentioned above. ${ }^{86}$ Recital 41 states that 'notice and action mecha-

\footnotetext{
82 European Commission, DSA Proposal (n. 81), 6.

83 European Commission, DSA Proposal (n. 81), 12.

84 European Commission, DSA Proposal (n. 81), 12.

85 European Commission, DSA Proposal (n. 81), Recital 3.

86 See above, IV.2., and Barker and Jurasz, Online Violence (n. 8), 57.
} 
nisms', ${ }^{87}$ should have rules that provide for robust safeguards to protect the rights and legitimate interests of all affected parties, including the right to non-discrimination as well as the right to non-discrimination of parties affected by illegal content. Recitals 52 to 63 are remarkable in that they mention the potential dangers of online advertisement, and in particular also recognises that online advertisement can contribute to significant risks, including the discriminatory display of advertising with an impact on the equal treatment and opportunities of citizens. This topic has recently become the subject of academic scrutiny ${ }^{88}$ and it is remarkable that the EU is taking it up already, including the subject of online behavioural advertising which poses risks of discrimination. And finally, what is notable is that Recital 91 states that the European Board for Digital Services should not only be allowed to cooperate with Union bodies in the field of data protection, electronic communications, audio-visual services, and others, but also Union bodies in the fields of 'equality, including equality between women and men, and nondiscrimination'. Such cooperation could ensure that equality considerations are taken seriously when deciding on matters of Internet governance within the European Union.

The attention devoted to equality in the Explanatory Memorandum and the Recitals is remarkable, particularly in comparison to the other documents analysed here. However, the Recitals themselves are not binding. They mainly serve to clarify the content and meaning of the substantive articles. Therefore, the more concrete and more important provisions are to be found in the articles of the proposed regulation. These, on the other hand, are rather thin as far as equality and non-discrimination are concerned. In that sense, equality only figures as one of the additional obligations for very large online platforms to manage systemic risks, in the sense that they have to conduct a risk assessment (Article 26), in which they identify, analyse, and assess at least once a year any significant systemic risks stemming from the functioning and use made of their services in the Union. This assessment shall include, amongst others, the risks of any negative effects for the exercise of the fundamental rights to respect for private and family life, freedom of expression and information, the prohibition of discrimination and the rights of the child. If such a risk is found, the platform has to take measures to mitigate

87 Such mechanisms facilitate the notification of specific items of information that the notifying party considers to be illegal content to the provider of hosting services concerned, pursuant to which that provider can decide whether or not it agrees with that assessment and wishes to remove or disable access to that content, see European Commission, DSA Proposal (n. 81), Recital 12.

88 See Sandra Wachter, 'Affinity Profiling and Discrimination by Association in Online Behavioural Advertising', Berkeley Technology Law Journal 35 (2020), 1-74. 
the risks, such as, for example, adapting content moderation or recommender systems or the display of advertisements in association with the service they provide (Article 27). The only other provision where equality and nondiscrimination are mentioned is Article 37, which would allow the EU Commission to set up so-called 'crisis protocols' for addressing crisis situations affecting public security or public health. Those protocols, according to Article 37(4)(d), must contain safeguards to avoid negative effects on, inter alia, the freedom of expression and the right to non-discrimination.

All in all, the Proposal for a Digital Services Act does go further than previous Internet governance documents in some areas by recognising different dimensions of inequality. Ultimately, however, the proposal does not go as far as it could have, because the noble words and promises in the recitals are not mirrored as concrete commitments in the substantive articles.

\section{The State of Equality in Internet Governance: An Interim Conclusion}

The content analysis of key documents of Internet governance from a variety of actors reveals no consistent or comprehensive approach to addressing the problem of networked inequality. While all the documents examined address some elements of equality, many of them seem more like a general commitment to abstract values rather than to concrete and enforceable rights, and all of them are incomplete because they address only one of the different dimensions of cyber-equality. Moreover, none of the documents examined seems to address the root causes of cyber-inequality.

Insofar as the analysed documents originate from private actors, it cannot be said that these actors have a direct duty to conform with International Human Rights standards of equality and non-discrimination, because private actors are not duty-bearers.

However, the lack of sensitivity to equality issues that emerges in these documents is problematic for the issue of cyber-equality for there is a danger that existing inequalities will be perpetuated, and new ones might not be detected. In fact, research has shown that inequalities that exist in the analogue world are reproduced in the digital world. Existing societal power structures are transferred to the Internet and repeated and sometimes even amplified there. ${ }^{89}$ Technodeterminism and the perceived neutrality of technology contribute to the public and academia turning a blind eye to such

89 See Hargittai and Hsieh (n. 7); Wessels (n. 7). 
inequality dynamics. This might also lead to 'covered-up' inequalities, inscribed into technology, hidden behind a seemingly neutral Internet architecture, and difficult to challenge legally.

Also, the characteristics of the current Internet governance regime provide little incentives for those responsible to act. It seems, for example, that the libertarian 'hands off'-approach to Internet governance, such as mirrored, inter alia, in the Declaration of independence of cyberspace, ${ }^{90}$ can have inegalitarian outcomes. And unclear regulatory patterns, diffuse accountability structures, obscured responsibilities, a variety of actors, polycentric regulation, rule-making pluralism, and fragmentation, ${ }^{91}$ as well as privatised Human Rights governance, ${ }^{92}$ further add to this situation. In sum, there are several structural barriers that hinder the effective embedding of equality considerations in Internet governance. This is reason enough to trigger an obligation for States to intervene under their Human Rights duties to guarantee equality and protect individuals against discrimination.

\section{Equality in Internet Governance: The Way Forward}

Equality is a fundamental value and a basic principle of liberal democratic societies and is mirrored in several international treaties, customs, principles, and procedures. This contribution has analysed key documents of Internet governance from an equality perspective, paying particular attention to three dimensions of networked inequality. The analysis revealed that there is no consistent or comprehensive approach to addressing the problem of networked inequality. In view of the various existing cyber-inequalities and the lack of engagement with equality issues in key documents of Internet governance, there seems to be a need for State intervention. The present study can be seen as a first step with a limited selection of cases. More research will be needed to better understand the topic and to embed equality considerations in Internet governance. To conclude this article, I will therefore sketch a research agenda to define a way forward that would help advance the cause of anchoring equality in international Internet law.

First, to gain a more complete overview of equality in Internet governance, more sources could be analysed. This could include the various outcome

90 John P. Barlow, A Declaration of the Independence of Cyberspace, 1996, available online at $<$ https://www.eff.org/.

91 See Rolf H. Weber, 'Elements of a Legal Framework for Cyberspace', SRIEL 26 (2016), 195-215 (203).

92 Zalnieriute (n. 6), 66. 
documents of the annual Internet Governance Fora, further internet-related regulations and directives of the European Union, recommendations and statements of the Council of Europe and the Organisation for Economic Cooperation and Development (OECD), laws at the national level, basic documents of bottom-up initiatives such as the Internet Society and the Internet Engineering Task Force, statements and reports of the various organs and rapporteurs of the United Nations, and many more. Existing international hard law instruments such as the Budapest Convention on Cybercrime should also be critically examined.

In a next step, it would be necessary to engage with the topic on a more abstract, theoretical level. This would involve a critical study of cyber-equality in international and European law, especially in their sub-fields of Human Rights protection. The Human Rights doctrine and practice in the field of cyberlaw must be developed further beyond freedom of expression and the right to privacy to also include the right to equality and non-discrimination. Important questions arise here, including: In cyberspace, with its fragmented and sometimes unclear governance structures, who is responsible for guaranteeing equality and non-discrimination? Which inequalities do constitute a violation of Human Rights? What positive obligations do States and the international community have to enforce the principle of equality and nondiscrimination between private parties? What negative obligations do states have in the field of cyber-equality (for example, when it comes to preventing negative side-effects of platform regulation on Human Rights)?

Since the intersecting categories of inequality that exist in the offline world usually continue online and are sometimes even amplified, research on cyberequality must apprehend equality both as a structural principle as well as an individual right. To make cyberspace more egalitarian, it is therefore not enough to create individual measures against discrimination (e.g. complaint possibilities), but systems must be designed in such a way that they prevent discrimination and inequalities in cyberspace as far as possible or do not allow them in the first place. One example could be the technique of 'equality mainstreaming, ${ }^{93}$ which could be applied in the design of Internet governance. However, it is no longer sufficient to focus exclusively on binary categories of equality (e.g. men/women). A contemporary engagement with cyber-equality must also take into account intersectional, queer-feminist, and postcolonial approaches.

93 Mainstreaming was developed in the context of gender equality and refers to the process of assessing the implications for men and women of any policy, program, or legislation, with the ultimate aim to achieve gender equality, see Hilary Charlesworth, 'Not Waving but Drowning: Gender Mainstreaming and Human Rights in the United Nations', Harvard Human Rights Journal 18 (2005), 1-18. 
Engaging with equality theory in Internet research would allow us to critically question existing and accepted values of Internet governance such as openness or universality. ${ }^{94}$ While laudable and important from a democratic perspective, these values represent ideas of formal equality which can, when applied to situations characterised by structural inequality, lead to outcomes that are at odds with the principle of substantive equality. Meritocratic ideas, which are underlying statements such as the following one, turn a blind eye to structural imbalances based on gender, race, and class: ${ }^{95}$ it is the craft of your work and the elegance and power of your solution that commends it and gives it power. Not your status, not your rank, not your corporate position, not your friendships, but your code: running code, that by its power produces rough consensus. ${ }^{96}$ It is equality and diversity theory which enables us to critically engage with such long-held values and beliefs in Internet governance and thus ultimately to avoid the 'online world' to further drift apart from established democratic values and principles from the 'offline world'.

94 For those values see for example Lessig (n. 4).

95 See, for example, Jo Littler, Against Meritocracy: Culture, Power and Myths of Mobility (London: Routledge 2017); Squires (n. 20), 478.

96 Lessig (n. 4), 1418. 